\title{
University Students' Opinion on Urban Agriculture Course: A Case Study
}

\author{
DOI: 10.26466/opus.928253
}

\author{
* \\ Hüseyin Berk Türker * \\ * Dr., Uşak University, Uşak/Turkey \\ E-Mail: berk.turker@usak.edu.tr \\ ORCID: $0000-0002-8995-3259$
}

\begin{abstract}
Urban agriculture is one of the most popular sustainable concepts in the world and Turkey recently. There are various programs and courses for urban agriculture education in universities around the world. However, urban agriculture education in Turkey is still developing. Therefore, Uşak University has recently started offering an urban agriculture course to undergraduate students. This course aims at increasing their awareness and knowledge of urban agriculture. It is the first urban agriculture course at the undergraduate level in Turkey. This study aims to determine the opinions of Usak University 3 rd-grade students about urban agriculture courses and their attitudes towards urban agriculture after the course. An online questionnaire was conducted for 40 undergraduate students from different departments who enrolled in an urban agriculture course. The questionnaire consisted of 19 questions including multiple-choice, yes/no, and fill-in-the-blank question types. In this study, descriptive statistical methods were used and answers were sought for sub-problems using the chi-square test. As a result of the research, it was concluded that the student's opinions of the course were positive, course content and materials were sufficient and the course was considered suitable for e-learning. In addition, it was observed that the awareness of urban agriculture increased at the end of the course.
\end{abstract}

Key Words: Urban Agriculture Education, Urban Agriculture Course, Urban Agriculture, Agriculture, Online Education. 


\section{Üniversite Öğrencilerinin Kentsel Tarım Dersine Yönelik Bakış Açıları}

*

\section{Öz}

Kentsel tarım son zamanlarda dünyada ve ülkemizde öne çıkan sürdürülebilir popüler konseptlerden biridir. Dünya'da üniversitelerde kentsel tarım eğitimine yönelik çeşitli programlar ve dersler bulunmaktadır. Fakat ülkemizde kentsel tarım eğitimi olduça yetersiz düzeydedir. Uşak Üniversitesi lisans düzeyi öğrencilerine yönelik üniversitenin ortak seçmeli dersler havuzu için alan dışı seçmeli ders olarak kentsel tarım dersi açılmıştır. Bu ders Türkiye'de lisans düzeyindeki ilk kentsel tarım dersidir ve öğrencilerin kentsel tarıma ilişkin farkındalıklarının ve bilgi düzeylerinin artırılmasını hedeflenmiştir. Bu araştırmada. Uşak Üniversitesinin farklı bölümlerinden 3. sını öğrencilerinin seçmeli ders olarak seçtikleri kentsel tarım dersine yönelik görüşlerinin araştırılması amaçlanmıştır. Araştırmada 2019-2020 Bahar dönemi kentsel tarım soru dersini alan 40 lisans öğrencisine çoktan seçmeli, evet / hayır ve boşluk doldurma tiplerini içeren 19 sorudan oluşan bir online anket uygulanmıştır. Verilerin analizi için SPSS Statistics 24 paket programında yer alan tanımlayıcı istatistiksel analiz yöntemleri ve ki-kare testinden faydalanılmıştır. Araştırma sonucunda öğrencilerin kentsel tarım dersine ilişkin görüşlerinin olumlu olduğu, ders içeriği ve materyallerinin yeterli olduğu ve dersin online eğitim için uygun olduğu sonucuna ulaşılmıştır. Ayrıca dersin sonunda kentsel tarıma olan farkındalığın arttığı gözlemlenmiştir.

Anahtar Kelimeler: Kentsel Tarım Eğitimi, Kentsel Tarım Dersi, Kentsel Tarım, Kent Tarımı, Online Eğitim. 


\section{Introduction}

Urban agriculture is a combination of urban and agricultural concepts. Mouget (2000) defined urban agriculture as an industry concerned with the production, distribution, and marketing of food and non-food products in the urban and peri-urban areas. It is understood from this definition that it has a wide range of economic activities from production to marketing and distribution. In addition to the economic activity of urban agriculture, it has important contributions to the ecological (Doherty, 2015) and social (Pearson and Hodgkin, 2010) systems of cities. It also has an impact on the health of the poor groups (Duchemin et al, 2008). Urban agriculture has some problems as well as its benefits (Bryld, 2003).

Urban agriculture is a popular phenomenon and people's awareness about it is increasing day by day. According to Orsini et al (2013) education and awareness are important for urban agriculture practices. Urban agriculture practices in schools create awareness among students about urban agriculture (United Nations, 2015). However, there are few studies focused on urban agriculture education. Pourjavid et al (2020) examined the effectiveness of urban agriculture education courses in Tehran, Iran. Travaline and Hunold (2010) revealed participation and education in Philadelphia.

Recently, public interest in agro-food concepts in America has increased (Weissman, 2015). Today, there are many urban agriculture programs opened in many universities in the USA and most of them are online. For instance, Purdue University-Urban Agriculture certificate (Purdue University, 2021), University of Guelph-Sustainable Urban Agriculture Certificate (University of Guelph, 2021), Virginia State UniversitySustainable Urban Agriculture Certıfıcate Program (Virginia Stage University, 2021). Oregon State University-Online Urban Agriculture program (Oregon State University, 2021).

There are a few courses about urban agriculture in universities in Turkey as well. However, these are post-graduate courses (Bartin University, 2021; Cankırı Karatekin University, 2021). Therefore, an urban agriculture course has been opened for undergraduate students of Usak University to increase students' awareness and knowledge about urban agriculture. The 
objective of this study is to investigate the opinions of these undergraduate students in different departments of Usak University about the urban agriculture course and a shift in their attitudes towards urban agriculture after the course. In this context, a survey study was conducted with the students who got themselves enrolled in the course.

\section{Materials and Methods}

\section{Course Description}

Usak University is located in Usak, Turkey. As of 2020, there are a total of 14 faculties, 1 school, 11 vocational schools, 3 institutes, and 27 research application centers (Usak, 2020). An urban agriculture course was offered in the spring semester of 2019-2020 for 3rd-grade students in Usak University under the general elective courses and started with face-to-face training. However, this course continued online due to the pandemic. The aim of this course is to introduce urban agriculture to students and to explain the basic concepts and current approaches in urban agriculture. The curriculum for this course has been designed by considering urban agriculture courses in other universities and related literature. The course content is as follows in Table 1.

Table 1. The course content

\begin{tabular}{ll}
\hline 1.Week & General Information of Urban Agriculture \\
2.Week & Food Security \\
3.Week & History of Urban Agriculture \\
4.Week & Typology of Urban Agriculture \\
5.Week & Dimensions of Urban Agriculture \\
$\mathbf{6 . W e e k}$ & Benefits of Urban Agriculture \\
7.Week & Mid-Term Exams \\
8.Week & Constraints of Urban Agriculture \\
9.Week & Trends in Urban Agriculture \\
$\mathbf{1 0 . W e e k}$ & Examples of Urban Agriculture Around the World \\
$\mathbf{1 1 . W e e k}$ & Urban Agriculture in Turkey \\
$\mathbf{1 2 . W e e k}$ & Practicing Urban Agriculture \\
$\mathbf{1 3 . W e e k}$ & Practicing Urban Agriculture \\
$\mathbf{1 4 . W e e k}$ & Final Exams \\
\hline
\end{tabular}




\section{Aim of the Questionnaire}

The questionnaire aims to reveal the opinions of the 3rd-grade students of Usak University about the urban agriculture course and a change in their attitudes towards urban agriculture after the course. An online survey was applied to 40 students who enrolled in the urban agriculture course after the final exam.

\section{Problem Statement of the Research:}

Do student's opinions on the urban agriculture course differ according to various variables?

\section{Sub-problems:}

- Is there a relationship between the reasons for choosing a course and the student's gender?

- Is there a relationship between the reasons for choosing a course and the department?

- Is there a relationship between reasons for choosing the course and the place where they have spent their life?

\section{Questionnaire Design}

The questionnaire consists of three parts and a total of 17 questions. In the first part of the questionnaire, there were 5 questions for demographic information. There were 5 questions to determine the attitudes of urban agriculture after the course. There were 7 questions to find out opinions about the urban agriculture course in the third part of the questionnaire. Survey questions consisted of multiple-choice, open-ended, and Yes / No question types. The prepared questions were designed to be clear and understandable to everyone. For reliable results, personal information was not requested when filling out the questionnaire. 


\section{Data Evaluation}

The results of the survey conducted with Google Forms were evaluated using IBM SPSS STATISTICS 24 package software. The data downloaded in Excel format was added to the SPSS database. Descriptive statistical methods were used to analyze the data. In the research, the questions were examined to determine whether the sub-problems differed statistically or not. Since the data did not show normal distribution, it was investigated which groups were statistically significant by applying the chi-square method.

\section{Results}

\section{Demographic Characteristics of Students}

The demographic characteristics of the survey participants are shown in Table 2. $47.5 \%$ of the students were female, and $52.5 \%$ were male. Most of the students were 22 years old ( $40 \%)$. Students were studying in the Department of Geography (5\%), Turkish Language and Literature (10\%), Agriculture (30\%), Department of Social Services (5\%), Department of Public administration (10 \%), Department of Civil Engineering (10\%), Department of Nursing Care (5\%), International Logistics (10\%), Finance (5\%), Business Administration (5\%), Journalism (2.5\%), History (2.5\%). Most of these students were studying in the third class. 20\% of the participants spent most of their lives in a metropolitan city, $17.5 \%$ in a province, $27.5 \%$ in a district, and $35 \%$ in a village or town.

Table 2. Demographic characteristics of students

\begin{tabular}{llll}
\hline & & N & Percentage (\%) \\
\hline Gender & Female & 19 & 47.5 \\
& Male & 21 & 52.5 \\
& Total & $\mathbf{4 0}$ & $\mathbf{1 0 0}$ \\
\hline Age & 20 & 4 & 10 \\
21 & 16 & 40 \\
& 22 & 8 & 20 \\
23 & 5 & 12.5 \\
& 24 & 5 & 12.5 \\
27 & 1 & 2.5 \\
& 42 & 1 & 2.5 \\
\hline
\end{tabular}




\begin{tabular}{|c|c|c|c|}
\hline & Total & 40 & 100 \\
\hline \multirow[t]{13}{*}{ Department } & Geography & 2 & 5 \\
\hline & $\begin{array}{l}\text { Turkish Language and Liter- } \\
\text { ature }\end{array}$ & 4 & 10 \\
\hline & Agriculture & 12 & 30 \\
\hline & Social Service & 2 & 5 \\
\hline & Public Administration & 4 & 10 \\
\hline & Civil Engineering & 4 & 10 \\
\hline & Nursing Care & 2 & 5 \\
\hline & International Logistics & 4 & 10 \\
\hline & Finance & 2 & 5 \\
\hline & Business & 2 & 5 \\
\hline & Journalism & 1 & 2.5 \\
\hline & History & 1 & 2.5 \\
\hline & Total & 40 & 100 \\
\hline \multirow[t]{3}{*}{ Class } & 3 & 38 & 95 \\
\hline & 4 & 2 & 5 \\
\hline & Total & 40 & 100 \\
\hline \multirow{5}{*}{$\begin{array}{l}\text { Where did you spend most of } \\
\text { your life? }\end{array}$} & Metropolis & 8 & 20 \\
\hline & Province & 7 & 17.5 \\
\hline & District & 11 & 27.5 \\
\hline & Village/Town & 14 & 35 \\
\hline & Total & 40 & 100 \\
\hline
\end{tabular}

\section{Attitude Towards Urban Agriculture}

Most of the students grew crops at their houses (67.5\%). This figure revealed the students who were doing urban gardening at home. $50 \%$ of the students heard the "urban agriculture" term before this course. To the question of "would you like to volunteer in the community garden?" 65\% of the students answered "Yes". $70 \%$ of the students wanted to earn income by working in the community garden and $85 \%$ of the students wanted to buy urban agriculture products (Table 3).

Table 3. Attitude towards urban agriculture

\begin{tabular}{llll}
\hline & N & Percentage (\%) \\
\hline $\begin{array}{llll}\text { Do you grow any crops at } \\
\text { your home? }\end{array}$ & Yes & 27 & 67.5 \\
& Total & 13 & 32.5 \\
\hline Have you heard "urban & Yes & $\mathbf{4 0}$ & $\mathbf{1 0 0}$ \\
agriculture" term before & No & 20 & 50 \\
the lesson & Total & 20 & 50 \\
Would you like to volun- & Yes & $\mathbf{4 0}$ & $\mathbf{1 0 0}$ \\
teer in the Community & No & 26 & 65 \\
Garden? & Not sure & 3 & 7.5 \\
& Total & 11 & 27.5 \\
\hline
\end{tabular}




\begin{tabular}{llll}
\hline $\begin{array}{l}\text { Do you want to earn in- } \\
\text { come by working in the }\end{array}$ & No & 28 & 70 \\
community garden? & Not sure & 5 & 12.5 \\
& Total & 7 & 17.5 \\
\hline Would you like to buy ur- Yes & $\mathbf{4 0}$ & $\mathbf{1 0 0}$ \\
ban agriculture products? & No & 34 & 85 \\
& Not sure & 1 & 2.5 \\
& Total & 5 & 12.5 \\
& $\mathbf{4 0}$ & $\mathbf{1 0 0}$ \\
\hline
\end{tabular}

\section{Opinions Towards Urban Agriculture Course}

Table 4 shows the opinions towards the urban agriculture course. It was extracted from the results that most of the participants found this course interesting (95\%).

An open question, "What is the reason for choosing the course" was asked to the students, and the answers were categorized (Table 4). The majority of students chose it because it was interesting (42.5\%). $97.5 \%$ of the participants thought that this course contributed positively to them. Most of the students $(92.5 \%)$ stated that their awareness of urban agriculture increased. $2.5 \%$ stated that their awareness of green spaces increased. The rest of the students answered that it made positive contributions to their future business plans. Most of the students found the course contents $(90 \%)$ and materials $(87.5 \%)$ adequate. $82.5 \%$ of the students thought that the course was suitable for e-learning.

Table 4. Opinions towards urban agriculture course

\begin{tabular}{|c|c|c|c|}
\hline & & $\mathbf{N}$ & Percentage $(\%)$ \\
\hline \multirow[t]{4}{*}{ Do you think the course was interesting? } & Yes & 38 & 95 \\
\hline & No & 2 & 5 \\
\hline & Not sure & 0 & 0 \\
\hline & Total & 40 & 100 \\
\hline \multirow[t]{8}{*}{ What is the reason for choosing the course? } & $\begin{array}{l}\text { The course attracted my atten- } \\
\text { tion. }\end{array}$ & 17 & 42.5 \\
\hline & There were no more courses left. & 3 & 7.5 \\
\hline & $\begin{array}{l}\text { The course is related to my de- } \\
\text { partment. }\end{array}$ & 8 & 20 \\
\hline & I chose it for my friend. & 3 & 7.5 \\
\hline & $\begin{array}{l}\text { I wanted to learn more about ur- } \\
\text { ban agriculture. }\end{array}$ & -5 & 12.5 \\
\hline & $\begin{array}{l}\text { I am interested in urban agricul- } \\
\text { ture. }\end{array}$ & 2 & 5 \\
\hline & $\begin{array}{l}\text { I chose it for my future agricul- } \\
\text { ture business. }\end{array}$ & 2 & 5 \\
\hline & Total & 40 & 100 \\
\hline
\end{tabular}




\begin{tabular}{|c|c|c|c|}
\hline \multirow{3}{*}{$\begin{array}{l}\text { Do you think the course has contributed posi- } \\
\text { tively to you? }\end{array}$} & Yes & 39 & 97.5 \\
\hline & Not sure & 1 & 2.5 \\
\hline & Total & 40 & 100 \\
\hline \multicolumn{2}{|c|}{ What was the positive contribution of the course For my future plans } & 2 & 5 \\
\hline \multirow[t]{3}{*}{ to you? } & $\begin{array}{l}\text { My awareness of green areas has } \\
\text { increased. }\end{array}$ & & 2.5 \\
\hline & $\begin{array}{l}\text { My awareness of urban agricul- } \\
\text { ture has increased. }\end{array}$ & 37 & 92.5 \\
\hline & Total & 40 & 100 \\
\hline \multirow[t]{4}{*}{ Were the course contents sufficient? } & Yes & 36 & 90 \\
\hline & No & 3 & 7.5 \\
\hline & Not sure & 1 & 2.5 \\
\hline & Total & 40 & 100 \\
\hline \multirow[t]{4}{*}{ Were the course materials sufficient? } & Yes & 35 & 87.5 \\
\hline & No & 2 & 5 \\
\hline & Not sure & 3 & 7.5 \\
\hline & Total & 40 & 100 \\
\hline \multirow[t]{4}{*}{ Is this course suitable for e-learning? } & Yes & 33 & 82.5 \\
\hline & No & 3 & 7.5 \\
\hline & Not sure & 4 & 10 \\
\hline & Total & 40 & 100 \\
\hline \multirow{4}{*}{$\begin{array}{l}\text { Do you think this course would be more benefi- } \\
\text { cial with distance education or formal educa- } \\
\text { tion? }\end{array}$} & Formal education & 4 & 10 \\
\hline & E-learning education & 32 & 80 \\
\hline & Not sure & 4 & 10 \\
\hline & Total & 40 & 100 \\
\hline Do you have any suggestions for the lesson? & $\begin{array}{l}\text { The course should be taught in } \\
\text { practice. } \\
\text { Urban agricultural areas should } \\
\text { be visited within the scope of the } \\
\text { course. }\end{array}$ & & \\
\hline
\end{tabular}

The students were asked their suggestions for this lesson in the last question of the questionnaire. There were two important suggestions that students generally offered for the improvement of the course. Students generally wanted this course to be applied practically and they also suggested that they should visit urban agriculture areas for better comprehension.

Table 5. Chi-square test results

\begin{tabular}{|c|c|c|c|c|c|c|}
\hline \multicolumn{7}{|c|}{ What is the reason for choosing the course? } \\
\hline $\begin{array}{l}\text { The } \\
\text { cours }\end{array}$ & \multicolumn{6}{|c|}{ The } \\
\hline \multicolumn{7}{|c|}{$\begin{array}{l}\text { I wanted } \\
\text { chose I am inter- more }\end{array}$} \\
\hline $\begin{array}{l}\text { at- } \\
\text { ten- } \\
\text { tion }\end{array}$ & $\begin{array}{l}\text { The course is } \\
\text { related to my } \\
\text { department }\end{array}$ & $\begin{array}{l}\text { my future agri- } \\
\text { culture busi- } \\
\text { ness }\end{array}$ & $\begin{array}{l}\text { - more } \\
\text { courses } \\
\text { left }\end{array}$ & $\begin{array}{l}\text { it for } \\
\text { my } \\
\text { friend }\end{array}$ & $\begin{array}{l}\text { ested in } \\
\text { agricul- } \\
\text { ture. }\end{array}$ & $\begin{array}{l}\text { about ur- } \\
\text { ban agri- } \\
\text { culture }\end{array}$ \\
\hline
\end{tabular}




\begin{tabular}{|c|c|c|c|c|c|c|c|c|c|}
\hline \multirow[t]{2}{*}{ Gender } & Male & 6 & 4 & 1 & 2 & 2 & 2 & 4 & 21 \\
\hline & Female & 11 & 4 & 1 & 1 & 1 & 0 & 1 & 19 \\
\hline Total & & 17 & 8 & 2 & 3 & 3 & 2 & 5 & 40 \\
\hline \multicolumn{10}{|c|}{$X^{2}$ Test $P=0,468>0,05$} \\
\hline \multirow[b]{4}{*}{$\begin{array}{l}\text { Where } \\
\text { did you } \\
\text { spend } \\
\text { most of } \\
\text { your } \\
\text { life? }\end{array}$} & Metropolis & 4 & 0 & 0 & 2 & 1 & 0 & 1 & 8 \\
\hline & Province & 3 & 2 & 0 & 0 & 0 & 0 & 2 & 7 \\
\hline & District & 7 & 1 & 1 & 0 & 1 & 0 & 1 & 11 \\
\hline & Village/Town & 3 & 5 & 1 & 1 & 1 & 2 & 1 & 14 \\
\hline Total & & 17 & 8 & 2 & 3 & 3 & 2 & 5 & 40 \\
\hline \multicolumn{10}{|c|}{$X^{2}$ Test $P=0,396>0,05$} \\
\hline \multirow{12}{*}{$\begin{array}{l}\text { Depart- } \\
\text { ment }\end{array}$} & Agriculture & 4 & 6 & 0 & 0 & 0 & 0 & 1 & 11 \\
\hline & $\begin{array}{l}\text { Turkish Lan- } \\
\text { guage and liter- } \\
\text { ature }\end{array}$ & 3 & 1 & 0 & 0 & 0 & 0 & 1 & 5 \\
\hline & Social Service & 1 & 0 & 0 & 0 & 0 & 1 & 0 & 2 \\
\hline & $\begin{array}{l}\text { Public Admin- } \\
\text { istration }\end{array}$ & 2 & 0 & 1 & 0 & 0 & 0 & 1 & 4 \\
\hline & $\begin{array}{l}\text { Civil Engineer- } \\
\text { ing }\end{array}$ & 0 & 1 & 0 & 1 & 1 & 0 & 1 & 4 \\
\hline & Nursing Care & 1 & 0 & 0 & 1 & 0 & 0 & 0 & 2 \\
\hline & $\begin{array}{l}\text { International } \\
\text { Logistics }\end{array}$ & 3 & 0 & 0 & 1 & 0 & 0 & 0 & 4 \\
\hline & Journalism & 1 & 0 & 0 & 0 & 0 & 0 & 0 & 1 \\
\hline & Business & 1 & 0 & 0 & 0 & 1 & 0 & 0 & 2 \\
\hline & History & 1 & 0 & 0 & 0 & 0 & 0 & 0 & 1 \\
\hline & Finance & 0 & 0 & 1 & 0 & 0 & 0 & 1 & 2 \\
\hline & Geography & 0 & 0 & 0 & 0 & 1 & 1 & 0 & 2 \\
\hline Total & & 17 & 8 & 2 & 3 & 3 & 2 & 5 & 40 \\
\hline
\end{tabular}

As can be seen from Table 5, sub-problems at the $\mathrm{P}<0.05$ level were examined with the chi-square test and no statistical relationship was found between them.

\section{Discussion}

This study aims to determine students' opinions about urban agriculture courses and their attitudes towards urban agriculture after the course. According to the results of this study, the course contributed positively to students $(\% 97,5)$ and the course was found interesting by students $(95 \%)$. 
According to the students, the course contents (90\%) and materials $(87.5 \%)$ were sufficient. These findings revealed that the opinions towards the urban agriculture course were generally positive and the course was interesting for students from different disciplines. The course material and content were also found sufficient for e-learning.

Most of the students participating in the research were engaged in urban agriculture (67.5\%). However, half of the students (50\%) had not heard of urban agriculture before. Despite not hearing the term urban agriculture, $42.5 \%$ of the students said "the course attracted my attention" $20 \%$ of the students shared "the course is related to my department" $12.5 \%$ of the students said "I wanted to learn more about urban agriculture" and $5 \%$ of the students expressed "I am interested in urban agriculture". Although half of the students never heard of urban agriculture, it was obvious that some of the students unconsciously answered the questions. In addition, it can be said that the students' urban agriculture attitude at the end of the course was positive because $65 \%$ of the students said that they could work voluntarily in the community garden and $85 \%$ of them said that they could buy urban agricultural products. It is noteworthy that at the end of the course some students (15\%) had some doubts about urban agricultural products.

Sub-problems of the research were examined and no statistical relationship was found between them. Also, the students stated that it was appropriate to conduct the course online. However, they generally thought that the course should be done in practice and urban agricultural areas should be visited. These suggestions of the students were planned for the face-to-face education period. However, due to the rapid transition to online education during the pandemic period, urban agriculture could not be demonstrated in practice. According to the results of the survey, it is seen that the students' awareness, opinions, and knowledge level towards urban agriculture have increased at the end of the course. Grossman et al (2012) concluded that the urban agriculture course provided students with valuable theoretical and empirical knowledge on access to food. Urban agriculture can be one of the main tools of new environmental education strategies that can increase one's sense of belonging and awareness about the environment (Ferreira et. al, 2018). Urban agriculture 
programs have important aspects in urban areas such as contact with nature, healthy nutrition, conventional environmental science, etc. (Reynolds, 2017)

The conscious and effective use of resources is critical for the development of countries. Also, education is an indispensable element. In Turkey, which has a very high agricultural potential, gaining the right agricultural awareness at young ages will greatly increase the quality of life (Haşiloğlu et. al, 2011).

In this study, the importance of online education in urban agriculture education was also revealed. The face-to-face education at the beginning of the course was suddenly switched to online education due to Covid 19, and it was observed that students in this course adapted to online education after face-to-face education. Baptista, et al (2021) stated that face-toface education is one of the important education methods considered for sustainable agriculture programs in higher education. However, their study revealed the importance of online education due to the Covid-19 pandemic. It has been revealed that information and education technology have important contributions to online education.

A major limitation of this study is the relatively small sample size. It requires to exercise caution when interpreting the results. However, the most important conclusion that can be drawn from this research is that the urban agriculture course increases the student's awareness of urban agriculture.

\section{Results and Suggestions}

This course is the first urban agriculture course for undergraduate students in universities in Turkey. The opinions of undergraduate students from different departments of the university on the urban agriculture course were determined. With this study, it has been proven that this course has many benefits. To make this course more effective:

- Visual materials and application examples from the world and our country should be used within the scope of the course.

- In face-to-face education, site visits must be added to the course.

- The course should be designed to be compatible with online education. 
- If the course will be held online, virtual platforms can be designed for urban agricultural areas.

- Urban agriculture education in our country is an innovative phenomenon. In this context, the development of urban agriculture education is an important issue. Increasing urban agriculture education in our country ensures the formation of more environmentally conscious societies. The following recommendations should be taken into account in order to provide efficient urban agriculture education:

- In Turkey, the number of urban agricultural experts is very low. Departments should be opened in relevant faculties in order to train urban agricultural experts or educators who can teach this course.

- Urban agriculture education programs should be developed, diversified, and necessary educational researches should be carried out.

- It would be beneficial to open an urban agriculture course in the department of city and region planning, architecture, landscape architecture, agriculture, and related departments.

- The opening of urban agriculture departments in vocational schools can meet the need for intermediate staff.

- Urban agriculture courses at primary, secondary, and high school levels can increase pre-high school students' awareness of urban agriculture.

- Urban agriculture courses should be opened in public education centers.

\section{References}

Bartin University, (2021). Retrieved 17 January, 2021 from http://ubys.bartin.edu.tr/.

Baptista, F., Lourenço, P., da Cruz, V. F., Silva, L. L., Silva, J. R., Correia, M., Picuno, P., Dimitriou, E. and Papadakis, G. (2021). Which are the best practices for MSc programmes in sustainable agriculture?. Journal of Cleaner Production, 303, 126914. 
Bryld, E. (2003). Potentials, problems, and policy implications for urban agriculture in developing countries. Agriculture and human values, 20(1), 79-86.

Cankırı Karatekin University, (2021). Retrieved 17 January, 2021 from http://of.karatekin.edu.tr/yukle/dpfbe2017b-pm.pdf.

Duchemin, E., Wegmuller, F. and Legault, A. M. (2008). Urban agriculture: Multi-dimensional tools for social development in poor neighbourhoods. Field Actions Science Reports. The Journal of Field Actions, 1(1), 43-52.

Doherty K., (2015). Urban agriculture and ecosystem services: a typology and toolkit for planners. University of Massachusetts Amherst, USA.

Ferreira, A. J. D., Guilherme, R. I. M. M. and Ferreira, C. S. S. (2018). Urban agriculture, a tool towards more resilient urban communities?. Current Opinion in Environmental Science \& Health, 5, 93-97.

Grossman, J., Sherard, M., Prohn, S. M., Bradley, L., Goodell, S. and Andrew, K. (2012). An exploratory analysis of student-community interactions in urban agriculture. Journal of Higher Education Outreach and Engagement, 16(2), 179-196.

Haşiloğlu, M. A., Kocaman, S. and Aydın, S. (2011). Tarım okuryazarlı̆̆ı ve tarım eğitimine bir bakış. Gazi Üniversitesi Gazi Eğitim Fakültesi Dergisi, 31(2), 619-629.

Mougeot, L. J., (2000). Urban agriculture: Definition, presence, potentials and risks, and policy challenges. Cities Feeding People Series, Report 31, p.58.

Oregon State University, (2021). Retrieved 17. January, 2021 from https://workspace.oregonstate.edu/courselurban-ag-program.

Orsini, F., Kahane, R., Nono-Womdim, R. and Gianquinto, G. (2013). Urban agriculture in the developing world: A review. Agronomy for sustainable development, 33(4), 695-720.

Pearson, D., Hodgkin, K., (2010). The role of community gardens in urban agriculture. In Community Garden Conference, (p.99).

Pourjavid, S., Poursaeed, A. and Mirdamadi, S. M. (2020). Modeling the effectiveness of urban agriculture education courses. Urban Ecosystems, 23, 927-932.

Purdue University, (2021). Retrieved 17. January, 2021 from https://www.purdue.edu/dffs/urbanag/programs-old/urban-ag-certificatel 
Reynolds, K. (2017). Designing urban agriculture education for social justice: Radical innovation through Farm School NYC. International Journal of Food Design, 2(1), 45-63.

Travaline, K. and Hunold, C. (2010). Urban agriculture and ecological citizenship in Philadelphia. Local Environment, 15(6), 581-590.

United Nations, (2015). Retrieved 17. January, 2021 from https://sustainabledevelopment.un.org/partnership/?p=30648.

University of Guelph, (2021). Retrieved 17. January, 2021 from https://courses.opened.uoguelph.ca/public/category/courseCategoryCertificateProfile.do? method=load\&certificateId $=615989$.

Usak University, (2021). Retrieved 17. January, 2021 from https://www.usak.edu.tr.

Virginia State University, (2021). Retrieved 17. January, 2021 from https://www.ext.vsu.edu/urban-agriculture-certificate-program.

Weissman, E. (2015). Entrepreneurial endeavors:(re) producing neoliberalization through urban agriculture youth programming in Brooklyn, New York. Environmental Education Research, 21(3), 351-364.

\section{Kaynakça Bilgisi / Citation Information}

Türker, H. B. (2021). University students' opinion on urban agriculture course: A case study. OPUS-International Journal of Society Studies, 18(44), 7505-7519. DOI: 10.26466/opus.928253. 